University of Nebraska - Lincoln

DigitalCommons@University of Nebraska - Lincoln

9-13-2018

\title{
Cover Crops and Returning Residue Impact on Soil Organic Carbon, Bulk Density, Penetration Resistance, Water Retention, Infiltration, and Soybean Yield
}

\author{
Kopila Subedi Chalise \\ South Dakota State University \\ Shikha Singh \\ South Dakota State University \\ Brianna R. Wegner \\ South Dakota State University \\ Sandeep Kumar \\ South Dakota State University \\ Juan D. Pérez-Gutiérrez \\ South Dakota State University \\ See next page for additional authors
}

Follow this and additional works at: https://digitalcommons.unl.edu/usdaarsfacpub

Chalise, Kopila Subedi; Singh, Shikha; Wegner, Brianna R.; Kumar, Sandeep; Pérez-Gutiérrez, Juan D.; Osborne, Shannon L.; Nleya, Thandiwe; Guzman, Jose; and Rohila, Jai S., "Cover Crops and Returning Residue Impact on Soil Organic Carbon, Bulk Density, Penetration Resistance, Water Retention, Infiltration, and Soybean Yield" (2018). Publications from USDA-ARS / UNL Faculty. 2139.

https://digitalcommons.unl.edu/usdaarsfacpub/2139

This Article is brought to you for free and open access by the U.S. Department of Agriculture: Agricultural Research Service, Lincoln, Nebraska at DigitalCommons@University of Nebraska - Lincoln. It has been accepted for inclusion in Publications from USDA-ARS / UNL Faculty by an authorized administrator of DigitalCommons@University of Nebraska - Lincoln. 


\section{Authors}

Kopila Subedi Chalise, Shikha Singh, Brianna R. Wegner, Sandeep Kumar, Juan D. Pérez-Gutiérrez, Shannon L. Osborne, Thandiwe Nleya, Jose Guzman, and Jai S. Rohila 


\title{
Cover Crops and Returning Residue Impact on Soil Organic Carbon, Bulk Density, Penetration Resistance, Water Retention, Infiltration, and Soybean Yield
}

\author{
Kopila Subedi Chalise, Shikha Singh, Brianna R. Wegner, Sandeep Kumar,* \\ Juan D. Pérez-Gutiérrez, Shannon L. Osborne, Thandiwe Nleya, Jose Guzman, and Jai S. Rohila
}

\begin{abstract}
Residue management with cover crops (CC) can conserve soil moisture and thus has a potential to increase crop yield, but its effectiveness varies significantly by region and cropping system management. A study was conducted at Brookings, SD, on finesilty, mixed, superactive, frigid, Calcic/Pachic Hapludolls soils to understand the impact of $\mathrm{CC}$ and crop residue on soil properties and soil-water dynamics for soybean (Glycine max L.) crop grown after corn (Zea mays L.). The site had two crop residue treatments (residue returned $[R R]$ and residue not returned $[R N R])$ under a no-till corn-soybean rotation. Each residue returned treatment was later subdivided to include $\mathrm{CC}$ and no CC (NCC) treatments. Results from this $3 \mathrm{yr}(2014,2015$, and 2016) study showed that $R R\left(1.30 \mathrm{Mg} \mathrm{m}^{-3}\right)$ had $7 \%$ lower bulk density (BD) compared to the RNR $\left(1.40 \mathrm{Mg} \mathrm{m}^{-3}\right)$. Soil organic carbon (SOC) was $22 \%$ higher under RR $\left(26.2 \mathrm{~g} \mathrm{~kg}^{-1}\right)$ compared to $\operatorname{RNR}\left(21.5 \mathrm{~g} \mathrm{~kg}^{-1}\right)$. Soil water infiltration was $66 \%$ higher under RR $\left(108 \mathrm{~mm} \mathrm{~h}^{-1}\right)$ compared to RNR $(64.8 \mathrm{~mm}$ $\left.\mathrm{h}^{-1}\right)$. Similarly, soil water infiltration in CC treatment $(111 \mathrm{~mm}$ $\left.\mathrm{h}^{-1}\right)$ was $80 \%$ higher compared to NCC $\left(61.7 \mathrm{~mm} \mathrm{~h}^{-1}\right)$. The RR with $\mathrm{CC}$ treatment increased soil volumetric water content and soil water storage. Overall, the CC increased soybean yield by $14 \%$ compared to NCC. Data from this study suggest that the use of CC with RR are beneficial for improving soil properties, conserving soil moisture and enhancing crop yield.
\end{abstract}

\section{Core Ideas}

- Residue returned increased organic carbon and reduced bulk density compared to residue not returned.

- Residue returned increased water retention and infiltration compared to residue not returned.

- Residue returned and cover crop increased soil volumetric water content and water storage.

- Cover crop reduced bulk density and increased water infiltration compared with no cover crop.

- Cover crop increased the soybean yield by $14 \%$ compared with no cover crop.
Published in Agron. J. 110:99-108 (2018)

doi:10.2134/agronj2018.03.0213

Copyright (c) 2018 by the American Society of Agronomy

5585 Guilford Road, Madison, WI 53711 USA

All rights reserved

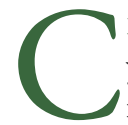
ROP RESIDUE removal has been increasing in recent years due to its demand for biofuel production and for short-term economic benefits to farmers (Muth and Bryden, 2013). It is estimated that over 207 million metric tons of corn (Zea mays L.) biomass will be removed for biofuel production by 2030 (Muth et al., 2013). However, the increasing rate of residue removal is estimated to create a threat to soil productivity (Mann et al., 2002; Muth and Bryden, 2013). Therefore, there was increased interest of retaining crop residue and use of cover crops (CC) for enhancing soil water dynamics (Blanco-Canqui and Lal, 2009b; Blanco-Canqui et al., 2015; Johnson et al., 2016). Removal of crop residue reduces soil organic carbon (SOC), and impacts soil productivity. However, the impacts of residue removal rates on soils depend on certain factors such as soil texture, soil topography, initial contents of SOC, tillage, and cropping system (Blanco-Canqui et al., 2013).

Water is the most limiting factor for crop production in regions where either irrigation is not available or precipitation is limited (Das et al., 2017). Water stored in the soil profile helps to fulfill the water requirement for following crop in the rotation. Corn residue left behind after corn harvest helps to conserve water in soil (Iqbal et al., 2013) and plays an important role in water conservation and hence increase grain yields where irrigation or precipitation is a limiting factor in crop production (Van Donk et al., 2010; VanLoocke et al., 2012).

The long-term adoption of CC could negate the adverse effects of residue removal and increase SOC and improve soil water dynamics, eventually improving crop production and soil productivity (Basche et al., 2016a; Basche et al., 2016b; Kahimba et al., 2008). A study by Chahal and Van Eerd (2018) showed that cover crop increased SOC concentrations by 8.4 to $9.3 \%$ and crop yield by 7.9 to $22 \%$ compared with no cover crop treatment. Basche and DeLonge (2017) showed that adoption of $\mathrm{CC}$ for more than $10 \mathrm{yr}$ improved soil hydrological properties

K.S. Chalise, B.R. Wegner, S. Kumar, J.D. Pérez-Gutiérrez, T. Nleya, J. Guzman, Dep. of Agronomy, Horticulture and Plant Science, South Dakota State Univ., Brookings, SD 57007; S. Singh, Univ. of Tennessee, Knoxville, TN 37996; S.L. Osbourne, USDA-ARS, NCARL, Brookings, SD 57006; J.S. Rohila, Dale Bumpers National Rice Research Center, USDA-ARS, Stuttgart, AR 72160. Received 26 Mar. 2018. Accepted 22 June 2018. ${ }^{*}$ Corresponding author (Sandeep.Kumar@sdstate.edu).

Abbreviations: BD, bulk density; CC, cover crop; NCC, no cover crop; RNR, residue not returned; RR, residue returned; SOC, soil organic carbon; SPR, soil penetration resistance; SWR, soil water retention; SWS, soil water storage; TC, total carbon; TN, total nitrogen; VWC, volumetric water content. 
such as total porosity and water retained at field capacity. Chu et al. (2017) also observed that CC increased soybean yield and gravimetric soil water content after $3 \mathrm{yr}$ of CC practice. Improved soil water management practices can reduce evaporation and runoff, which has positive impact on crop production (Jägermeyr et al., 2016). In some cases, cover crops have been shown to reduce water availability for the following cash crop reducing crop yield (Nielsen et al., 2016; Unger and Vigil, 1998). Conversely, many researchers have shown that the residue left after termination of cover crops helps to store more water in the soil profile (Alliaume et al., 2014; Basche et al., 2016b).

There are many unanswered questions on the significance of adopting CC and the rate of crop residue removal and their subsequent impacts on soils and crop yield in the upper US Great Plains. Therefore, this study was conducted to better understand the impact of crop residue and cover crops on soil water dynamics and soil properties. Specific objectives were to analyze the impacts of corn crop residue and cover crops on soil organic carbon and hydrological properties, and to assess the interaction between corn crop residue removal and CC on soil moisture, soil water storage, and soybean yield.

\section{MATERIALS AND METHODS}

\section{Experimental Design and Field Management}

The study was conducted at the USDA-ARS North Central Agricultural Research Laboratory, located in Brookings, $\mathrm{SD}\left(46^{\circ} 19^{\prime} \mathrm{N}, 96^{\circ} 46^{\prime} \mathrm{W}\right)$. Soil types of the study area were Kranzburg- Brookings silty loam complex; Kranzburg (fine-silty, mixed, superactive, frigid, Calcic Hapludolls) and Brookings (fine-silty, mixed, superactive, frigid Pachic Hapludolls). The experiment site was initiated in spring of 2000 under a no-till corn and soybean (Glycine max L.) rotation. Before establishing this experiment, the study area was continuously cropped with alfalfa (Medicago sativa L.) from 1995 to 1999. Initial bulk density, $\mathrm{SOC}$ and $\mathrm{pH}$ at $0-5 \mathrm{~cm}$ depth were $1.35 \mathrm{Mg} \mathrm{m}^{-3}, 27.8 \mathrm{~g} \mathrm{~kg}^{-1}$, and 6.7 , respectively with $47 \%$ sand, $6 \%$ clay and $47 \%$ silt. Two residue removal treatments that include residue returned (RR) and residue not returned (RNR) were established with three replicates in a randomized complete block design in the year 2000. In RR treatment, after grain harvesting all the remaining plant material was left in the surface. However, in RNR treatment, corn stalks of $0.15 \mathrm{~m}$ above the ground were left and all other corn biomass were removed. The average amount of $\mathrm{C}$ returned was 6.87 and $0.21 \mathrm{MgC} \mathrm{ha}^{-1}$ for the RR and RNR treatments, respectively (Hammerbeck et al., 2012). In fall 2005, two cover crop (CC) treatments; CC and no CC (NCC) were integrated into the overall design, adjusting the experimental design from a randomized complete block design to a split-plot design with three replications. Residue removal treatments were applied to the main plots and cover crops to the subplots. In RR treatment, only the grain was harvested and all the crop residue was left on the soil surface. However, in RNR treatment, all crop residue above $0.15 \mathrm{~m}$ from the ground was removed. The $\mathrm{CC}$ treatments consisted of a mixture of winter rye (Secale cereale L.) and hairy vetch (Vicia villosa L.) were planted after the corn harvest, and only hairy vetch was planted after the soybean harvest. Individual plot dimensions were $30 \times 30 \mathrm{~m}$. Additional details about the experimental site can be found in previous publications (e.g., Hammerbeck et al., 2012; Olson et al., 2010; Stetson et al., 2012). Data for this study was collected from 2014 through 2016.

Corn hybrid Viking $087-80 \mathrm{~N}$ and soybean variety Hefty H01R4 were seeded at the rate of 81,628 seeds ha ${ }^{-1}$ and 350,554 seeds ha ${ }^{-1}$, respectively, using a Kinze 3400 , with $50.8 \mathrm{~cm}$ row spacing. The mixture of CC (winter rye and hairy vetch) was seeded at the rate of $31.75-34.20 \mathrm{~kg} \mathrm{ha}^{-1}$. Before crop emergence, herbicides Sharpen (saflufenacil $29.74 \%$ a.i. $219 \mathrm{~mL}$ $\mathrm{ha}^{-1}$ ), Clarity (diglycolamine salt of 3, 6-dicholoro-o-anisic acid $41.9 \%$ a.i. $1.16 \mathrm{~L} \mathrm{ha}^{-1}$ ), Roundup Weathermax (glyphosate $48.8 \%$ a.i. $1.625 \mathrm{~L} \mathrm{ha}^{-1}$ ) and Dual II Magnum (s-metolachlor $82.4 \%$ a.i. [1.16 $\mathrm{L} \mathrm{ha}^{-1}$ ]) were applied. After the crop emergence herbicides Cadet (fluthiacet-methyl 10.3\% a.i. $1.23 \mathrm{~L} \mathrm{ha}^{-1}$ ) and Select Max (clethodim $12.6 \%$ a.i. $1.18 \mathrm{~L} \mathrm{ha}^{-1}$ ) were applied.

\section{Soil Sampling and Analysis}

Two intact soil cores $(5 \mathrm{~cm}$ diameter $\times 5 \mathrm{~cm}$ length $)$ per plot were collected on 22 Aug. 2014 and 23 July 2015 from 0-5 and $5-15 \mathrm{~cm}$ depths to measure total carbon (TC) and total nitrogen $(\mathrm{TN})$. In the laboratory, soils from each core were air-dried, and dry samples were sieved through a $2-\mathrm{mm}$ screen and processed for TC and TN. The TC and TN were analyzed using TruSpec CHN analyzer (LECO Corporation, St. Joseph, MI). In this study, soil inorganic carbon was found below detection levels, therefore, TC was considered as SOC for analyses purposes. Soil penetration resistance (SPR) was measured for $0-5$ $\mathrm{cm}$ and 5-15 cm depths using Eijelkamp-type hand penetrometer (Herrick and Jones, 2002). Five SPR readings in each plot were taken and the average value was used to represent SPR of each plot. Soil sample was also collected from the same depths at the time of SPR measurements for measuring the moisture content, and this moisture data was used to adjust the SPR using the relationship developed by Busscher and Bauer (2003).

In addition, intact core samples from $0-5$ and $5-15 \mathrm{~cm}$ were also collected to determine bulk density (BD) and soil water retention (SWR). Two soil cores from each plot in every replication were collected, labeled and sealed in plastic bags, and the extra soil from the intact cores was trimmed and removed from the core. The BD was calculated by dividing the oven-dried soil sample with the volume of soil core (Grossman and Reinsch, 2002). The SWR was measured for the $0-5$ and 5-15 cm depths. A cheese cloth was fixed at the bottom of intact soil cores, and these cores were prewetted by capillarity with water for 24 to $48 \mathrm{~h}$. The SWR was determined at seven matric potentials $\left(\Psi_{\mathrm{m}}\right)$ : a tension table method was used for five soil water potentials $(0,-0.4,-1.0,-2.5$, and $-5.0 \mathrm{kPa}$ ) (Amoozegar and Wilson, 1999), but the pressure plate methods was used for the two soil water potentials ( -10.0 and $-30.0 \mathrm{kPa})$ (Klute, 1986). Soil water content $\left(\mathrm{g} \mathrm{g}^{-1}\right)$ was determined gravimetrically by oven-drying the soil samples at $105^{\circ} \mathrm{C}$ for $48 \mathrm{~h}$. The conversion of gravimetric water content methods to volumetric water content $\left(\theta, \mathrm{m}^{3} \mathrm{~m}^{-3}\right)$ was based on the bulk density of the soil samples.

Soil infiltration rate $\left(q_{\mathrm{s}}\right)$ was measured in August 2014 and late June 2015 using a double-ring infiltrometer (ring of $30-\mathrm{cm}$ outer $\times 20$-cm inner diameter $\times 20 \mathrm{~cm}$ height) using a constanthead method (Reynolds et al., 2002). Two Infiltration measurements per plot were conducted for all the plots, until a steady state was achieved. Soil samples were collected for the analysis of 
Table I. Soil organic carbon (SOC), total nitrogen (TN), and soil penetration resistance (SPR) as influenced by residue returned and residue not returned, and cover crops for the $0-5$ and 5- 15 $\mathrm{cm}$ depths under soybean phase of corn-soybean rotation.

\begin{tabular}{|c|c|c|c|c|c|c|}
\hline & \multicolumn{6}{|c|}{ Depths $(\mathrm{cm})$} \\
\hline & $0-5$ & $5-15$ & $0-5$ & $5-15$ & $0-5$ & $5-15$ \\
\hline & \multicolumn{2}{|c|}{ SOC } & \multicolumn{2}{|c|}{$\mathrm{TN}$} & \multicolumn{2}{|c|}{ SPR } \\
\hline & \multicolumn{4}{|c|}{$-\mathrm{g} \mathrm{kg}^{-1}-\mathrm{g} \mathrm{kg}^{-1}$} & \multicolumn{2}{|c|}{$-\mathrm{MPa}$} \\
\hline \multicolumn{7}{|l|}{ Treatment } \\
\hline \multicolumn{7}{|l|}{ Residue } \\
\hline $\mathrm{RR} \dagger$ & $26.2 \mathrm{a} \ddagger$ & $21.0 \mathrm{a}$ & $2.14 \mathrm{a}$ & $1.75 \mathrm{a}$ & $2.23 \mathrm{~b}$ & $2.37 \mathrm{~b}$ \\
\hline RNR & $21.5 b$ & $19.8 \mathrm{a}$ & $1.83 b$ & $1.68 \mathrm{a}$ & $2.77 a$ & $3.01 \mathrm{a}$ \\
\hline \multicolumn{7}{|l|}{ Cover crop } \\
\hline $\mathrm{CC}$ & $24.0 \mathrm{a}$ & $20.6 a$ & $2.00 \mathrm{a}$ & $1.73 a$ & $2.24 b$ & $2.46 \mathrm{~b}$ \\
\hline \multirow[t]{2}{*}{$\mathrm{NCC}$} & $23.8 \mathrm{a}$ & $20.2 \mathrm{a}$ & $1.98 \mathrm{a}$ & $\mathrm{I} .7 \mathrm{Ia}$ & $2.76 a$ & $2.92 \mathrm{a}$ \\
\hline & \multicolumn{6}{|c|}{ Analysis of variance $(P>F)$} \\
\hline Residue (R) & $<0.01$ & 0.184 & $<0.01$ & 0.18 & 0.009 & 0.001 \\
\hline Crop (C) & 0.84 & 0.689 & 0.82 & 0.68 & 0.01 & 0.01 \\
\hline $\mathrm{R} \times \mathrm{C}$ & 0.06 & 0.326 & 0.054 & 0.32 & 0.07 & 0.03 \\
\hline
\end{tabular}

$\dagger R R$, residue returned; RNR, residue not returned; CC, cover crop; NCC, no cover crop.

$\ddagger$ Means values followed by different letters within a column for different treatments are significantly different at $P<0.05$.

initial gravimetric soil moisture content next to the place where infiltration measurements were conducted.

Soil samples were collected routinely to analyze for soil moisture content throughout the growing season from May through October 2016. Two soil samples per plot were collected with a standard hand held sampling auger from $0-5,5-15,15-30$, and $30-45 \mathrm{~cm}$ depths. Soil water storage was determined for upper $0-45 \mathrm{~cm}$ depth as more than $90 \%$ of active roots were located at this depth (Steduto, 2012). Soil samples were immediately weighed and placed in an oven to dry at $105^{\circ} \mathrm{C}$ for $48 \mathrm{~h}$ to measure gravimetric soil water content. Soil water storage was calculated using the equation as shown below:

$$
W=\sum_{i=1}^{n}\left(d_{i} \times \frac{\rho_{i}}{\rho_{w}} \times w_{i}\right) \times 10
$$

where, $d_{i}=$ depth interval for soil samples $(\mathrm{cm}), \rho=$ soil bulk density $\left(\mathrm{g} \mathrm{cm}^{-3}\right), \rho_{w}=$ density of water $\left(\mathrm{g} \mathrm{cm}^{-3}\right), w \mathrm{i}=$ gravimetric water content $\left(\mathrm{g} \mathrm{g}^{-1}\right),{ }_{i}$ refers to soil layers, and $n$ to the number of soil layers. The units for water storage $(W)$ was $\mathrm{mm}$.

Grain yields were measured by harvesting $15 \mathrm{~m}$ two central rows of each plot with a Massey Ferguson MF 8- XP research plot combine (Kincaid Equipment Manufacturing, Haven, KS). The grain yield was adjusted to $13 \%$ seed moisture content.

\section{Statistical Analysis}

Statistical analysis of crop residue returned (RR) and cover crop (CC) effects on the selected soil properties for each depth and year, and soybean yield in 2016 were obtained using pairwise differences method to compare least-squares means estimated by mixed models using the GLIMMIX procedure in SAS9.4 (SAS, 2013), where RR, CC, RR $\times$ CC were considered as fixed effects and replication as the random effect. The analysis of variance (ANOVA) was used to test the fixed effects of $\mathrm{RR}$ and $\mathrm{CC}$ on soil properties based on the mixed models. If the effect of $\mathrm{RR} \times \mathrm{CC}$ on a parameter was significant, the data were separately analyzed for each RR and CC. Data were
Table 2. Interaction effects of residue and cover crops on soil penetration resistance (SPR) for $5-15 \mathrm{~cm}$ depth. $\dagger$

\begin{tabular}{|c|c|c|}
\hline \multirow[b]{2}{*}{ Treatment } & \multicolumn{2}{|c|}{ SPR } \\
\hline & $\mathrm{CC}$ & $\mathrm{NCC}$ \\
\hline & & \\
\hline RR & $2.33 \mathrm{aA} \ddagger$ & $2.4 \mathrm{IbA}$ \\
\hline RNR & $2.57 \mathrm{aB}$ & $3.43 \mathrm{aA}$ \\
\hline
\end{tabular}

$+R R$, residue returned; $R N R$, residue not returned; $C C$, cover crop; NCC, no cover crop.

$\ddagger$ Average value followed by same lowercase letter within a column and by capital letter within each row are not significantly different at $P<0.05$.

transformed when necessary, and the transformation was determined using the Box-Cox method (Box and Cox, 1964, 1981). Statistical differences were declared significant at $\alpha=0.05$ level.

\section{RESULTS AND DISCUSSION}

\section{Soil Organic Carbon, Total}

\section{Nitrogen, and Soil Penetration Resistance}

The SOC under RR (26.2 $\left.\mathrm{g} \mathrm{kg}^{-1}\right)$ was $21.8 \%$ higher as compared to that under RNR $\left(21.5 \mathrm{~g} \mathrm{~kg}^{-1}\right)$ for the $0-5 \mathrm{~cm}$. Cover crop did not impact SOC and TN at both the soil depths (Table 1). The TN under RR treatment $\left(2.14 \mathrm{~g} \mathrm{~kg}^{-1}\right)$ was $17 \%$ higher as compared to that under $\operatorname{RNR}\left(1.83 \mathrm{~g} \mathrm{~kg}^{-1}\right)$. The interactions of residue by cover crop on SOC and TN were not significant at any depth. A study that was conducted in Ohio on silt loam and clay loam soils with $0,25,50,75$, and $100 \%$ of residue removal treatments found higher SOC with a higher residue retention rate in silt loam soil under long-term no-till continuous corn (Blanco-Canqui and Lal, 2007). Another study conducted in Brookings, SD, with similar soil type showed that increase in SOC was due to the retaining crop residue in the soil surface, as microbes break down the residue and store $\mathrm{C}$ in the soil surface (Stetson et al., 2012). In addition to SOC, the crop residue removal rate also impacted the TN. Blanco-Canqui and Lal (2009a) reported that complete removal of residue under continuous no-till corn reduced the TN pool by $0.82 \mathrm{Mg} \mathrm{ha}^{-1}$ in silt loam soils. Similarly, a multi-location study conducted at 28 locations in the corn belt region of the United States showed that with high removal of corn stover $\left(7.2 \mathrm{Mg} \mathrm{ha}^{-1}\right), 47 \mathrm{~kg} \mathrm{ha}^{-1}$ $\mathrm{N}$ was removed while moderate removal of corn stover $(3.9 \mathrm{Mg}$ $\mathrm{ha}^{-1}$ ) removed $24 \mathrm{~kg} \mathrm{ha}^{-1} \mathrm{~N}$ (Karlen et al., 2014). Removal of residue directly reduces the amount of $\mathrm{N}$ added to the soil. In the present study, CC did not impact the SOC at any depth. Similar results were observed in previous studies on a similar site (e.g., Wegner et al., 2015). Similarly, another study showed that CC did not increase SOC, however, they minimized the SOC loss (e.g., Olson et al., 2010). In some situations, it takes a few years before cover crops started showing beneficial impacts on SOC and other soil properties, hence long-term assessment is needed (Blanco-Canqui et al., 2014).

Residue removal and CC treatments reduced the SPR at $0-5$ and $5-15 \mathrm{~cm}$ depths (Table 1$)$. At the $0-5 \mathrm{~cm}$ depth, the mean SPR for the RR treatment $(2.23 \mathrm{MPa})$ was $24 \%$ lower as compared to the RNR (2.77 MPa). Similarly, mean SPR for $\mathrm{CC}(2.24 \mathrm{MPa})$ was $23 \%$ lower compared with the NCC $(2.76$ $\mathrm{MPa})$. No significant interactions were observed between residue removal and CC on SPR at $0-5 \mathrm{~cm}$ depth. However, for the 5-15 $\mathrm{cm}$ depth, interactions of the residue by $\mathrm{CC}$ treatments were significant $(P<0.03$; Tables 1 and 2$)$. Data showed that $\mathrm{RR}$ with 
Table 3. Soil bulk density (BD) as influenced by residue returned and residue not returned and cover crops for the $0-5$ and $5-15$ $\mathrm{cm}$ depths under soybean phase of corn-soybean rotation for 20I4, 20I5, and 2016.

\begin{tabular}{|c|c|c|c|c|c|c|}
\hline \multirow[b]{3}{*}{ Treatment $\dagger$} & \multicolumn{2}{|c|}{2014} & \multicolumn{2}{|c|}{2015} & \multicolumn{2}{|c|}{2016} \\
\hline & \multicolumn{4}{|c|}{ Depth $(\mathrm{cm})$} & \multirow[b]{2}{*}{$0-5$} & \multirow[b]{2}{*}{$5-15$} \\
\hline & $0-5$ & $5-15$ & $0-5$ & $5-15$ & & \\
\hline & & & $\mathrm{BD}(\mathrm{N}$ & $\left.\mathrm{g} \mathrm{m}^{-3}\right)$ & & \\
\hline \multicolumn{7}{|l|}{ Residue } \\
\hline $\mathrm{RR}$ & $\mathrm{l} .4 \mathrm{la}$ & $1.42 \mathrm{a}$ & $\mathrm{I} .30 \mathrm{~b}$ & $1.37 \mathrm{a}$ & $1.29 \mathrm{~b}$ & $\mathrm{I} .34 \mathrm{~b}$ \\
\hline RNR & $1.42 \mathrm{a}$ & $1.44 \mathrm{a}$ & $1.40 \mathrm{a}$ & $1.37 \mathrm{a}$ & $1.38 \mathrm{a}$ & $1.39 \mathrm{a}$ \\
\hline \multicolumn{7}{|l|}{ Cover Crop } \\
\hline $\mathrm{CC}$ & $1.40 \mathrm{a}$ & $1.43 a$ & $1.30 \mathrm{~b}$ & $1.36 \mathrm{a}$ & $1.32 \mathrm{a}$ & $1.33 \mathrm{~b}$ \\
\hline \multirow[t]{2}{*}{$\mathrm{NCC}$} & $1.43 \mathrm{a}$ & $1.43 \mathrm{a}$ & $1.39 \mathrm{a}$ & $1.38 \mathrm{a}$ & $1.35 \mathrm{a}$ & $1.40 \mathrm{a}$ \\
\hline & \multicolumn{6}{|c|}{ Analysis of variance $(P>F)$} \\
\hline Residue (R) & 0.68 & 0.62 & 0.001 & 0.83 & 0.001 & 0.006 \\
\hline Crop (C) & 0.30 & 0.92 & 0.005 & 0.13 & 0.11 & 0.002 \\
\hline $\mathrm{R} \times \mathrm{C}$ & 0.04 & 0.40 & 0.08 & 0.25 & 0.08 & 0.23 \\
\hline
\end{tabular}

$\dagger R R$, residue returned; RNR, residue not returned; CC, cover crop; NCC, no cover crop.

$\ddagger$ Means values followed by different letters within a column for different treatments are significantly different at $P<0.05$.

NCC treatment (2.41 MPa) had significantly lower SPR (by 42\%) compared with RNR with NCC treatment (3.43 MPa). Similarly, RNR with CC treatment $(2.57 \mathrm{MPa})$ had significantly lower SPR (by 33\%) compared with RNR with NCC treatment (3.43 MPa). Our results showed that $\mathrm{RR}$ reduced the SPR value in the $0-5 \mathrm{~cm}$ depth. Similar results were observed in a study conducted at Ames, IA, where high stover harvest increased the SPR value by $39 \%$ compared with no stover removal (Tormena et al., 2017). Similar results were also observed in a long-term study conducted in Ohio on silt loam soil in which the SPR value increased by 17 to $24 \%$ when $>50 \%$ of residues were removed compared to no residue removal (Blanco-Canqui and Lal, 2007). However, these results did not support the study conducted in Chazy, NY, where residue harvest did not impact the SPR compared to no harvest of residue (Moebius-Clune et al., 2008). Our results showed that CC reduced SPR value by $23 \%$ compared with that under NCC treatment. Similar results were observed in a study conducted in Illinois on silty clay loam (Acuña and Villamil, 2014). The RR with CC increase the accumulation of SOC and hence decrease the SPR.

\section{Soil Bulk Density}

In 2014, the BD under RR and RNR was not significantly different for the $0-5 \mathrm{~cm}$ depth (Table 3). However, the interactions between cover crops and crop residue were significant at 0-5 cm depth (Table 4). In 2015, the BD was impacted by the residue removal as well as by cover crops for $0-5 \mathrm{~cm}$ depth. The RR treatment $\left(1.30 \mathrm{Mg} \mathrm{m}^{-3}\right)$ had $7.6 \%$ lower BD compared to RNR $\left(1.40 \mathrm{Mg} \mathrm{m}^{-3}\right)$. Similarly, CC $\left(1.30 \mathrm{Mg} \mathrm{m}^{-3}\right)$ had $7 \%$ lower $\mathrm{BD}$ compared to NCC treatment $\left(1.39 \mathrm{Mg} \mathrm{m}^{-3}\right)$. However, no significant impact of residue removal and CC was observed for the $5-15 \mathrm{~cm}$ depth. In addition, no interactions were observed between the residue removal and CC treatments at both soil depths. A similar trend was observed in 2016. The RR treatment $\left(1.29 \mathrm{Mg} \mathrm{m}^{-3}\right)$ had a $7 \%$ lower BD compared to the RNR treatment $\left(1.38 \mathrm{Mg} \mathrm{m}^{-3}\right)$. However, significant impacts of $\mathrm{CC}$ and NCC treatments were not observed. For the $5-15 \mathrm{~cm}$ depth, residue removal, as well as cover crops significantly impacted
Table 4. Interaction effects of residue and cover crops on bulk density (BD) for $0-5 \mathrm{~cm}$ depth in 20l4.†

\begin{tabular}{lll}
\hline & \multicolumn{2}{c}{$\mathrm{BD}$} \\
\cline { 2 - 3 } Treatment & $\mathrm{CC}$ & $\mathrm{NCC}$ \\
\cline { 2 - 3 } RR & \multicolumn{1}{c}{$\mathrm{Mg} \mathrm{m}^{-3}$} & $1.35 \mathrm{aB} \ddagger$ \\
RNR & $\mathrm{I.44aA}$ & $1.40 \mathrm{aA}$ \\
\hline
\end{tabular}

†RR, residue returned; RNR, residue not returned; CC, cover crop; NCC, no cover crop.

$\ddagger$ Average value followed by same lowercase letter within a column and by capital letter within a row are not significantly different at $P<0.05$.

the BD. The BD for the RR treatment $\left(1.34 \mathrm{Mg} \mathrm{m}^{-3}\right)$ was $3.7 \%$ lower compared with the RNR $\left(1.39 \mathrm{Mg} \mathrm{m}^{-3}\right)$. The BD for the $\mathrm{CC}$ treatment $\left(1.33 \mathrm{Mg} \mathrm{m}^{-3}\right)$ was $5 \%$ lower compared to the NCC $\left(1.40 \mathrm{Mg} \mathrm{m}^{-3}\right)$. However, no interactions between the residue removal and cover crops treatments were observed in 2016. Data from a study conducted in Rosemont, $\mathrm{MN}$, and Ames, IA, showed 7\% higher BD with high residue removal rate compared to no harvest of residue (Dolan et al., 2006; Tormena et al., 2017). The present study showed that CC reduced BD for the $0-5 \mathrm{~cm}$ depth. Cover crops protect the soil from compaction, as well as increase SOC, which result in lower BD under cover crops compared with no cover crops (Dolan et al., 2006; Tormena et al., 2017). In the year 2016, we observed lower BD at both soil depths, which was probably due to root contributions. In 2016, it was observed that RR reduced $\mathrm{BD}$ by $7 \%$ and $3.7 \%$ for depth $0-5$ and $5-15 \mathrm{~cm}$, respectively, compared with BD under RNR treatment. Similar results were observed in another study conducted at Chazy, NY, with silt loam soil under corn production which showed that stover-returned had 5\% lower BD compared to stover-harvested (Moebius-Clune et al., 2008).

\section{Soil Water Retention}

For 2014, the RR treatment had a significantly higher soil water retention (SWR) compared with that under RNR at all seven pressures for the $0-5 \mathrm{~cm}$ depth (Fig. 1A). For $5-15 \mathrm{~cm}$ depth, the RR treatment had significantly higher SWR compared with RNR at 0 and $-0.4 \mathrm{kPa}$ (Fig. 1B). For the CC treatments, the CC had significantly higher SWR as compared to that under NCC at $0 \mathrm{kPa}$ for $0-5 \mathrm{~cm}$ depth (Fig. 1C). However, no significant differences were observed for $\mathrm{CC}$ treatments at any pressure for the $5-15 \mathrm{~cm}$ depth (Fig. 1D). For 2015, SWR for RR treatment was significantly higher at $-2.5 \mathrm{kPa},-5.0 \mathrm{kPa}$, $-10.0 \mathrm{kPa}$, and $-30.0 \mathrm{kPa}$ for the $0-5 \mathrm{~cm}$ depth compared with the RNR treatment (Fig. 1E). For $5-15 \mathrm{~cm}$ depth, RR treatment had a higher SWR than that under RNR only at 0 and $-0.4 \mathrm{kPa}$ (Fig. 1F). However, no significant differences were observed on SWR between the CC treatments at the $0-5 \mathrm{~cm}$ (Fig. 1G) and 5-15 cm depth (Fig. 1H).

Data showed that SWR was higher with RR due to higher $S O C$ and lower $\mathrm{BD}$ in this treatment compared to that under RNR. A similar finding was observed in a study conducted in Ohio, where RR had 20-50\% more water retained compared to that under RNR treatment (Blanco-Canqui and Lal, 2007). A positive relationship between $S O C$ and $S W R$ was reported by Rawls et al. (2003). Cover crop treatments did not affect SWR at all pressures except at $0 \mathrm{kPa}$ in 2014. The previous study conducted on the same experimental plots showed that there was no impact of cover crops on SWR (Wegner et al., 2015). In 

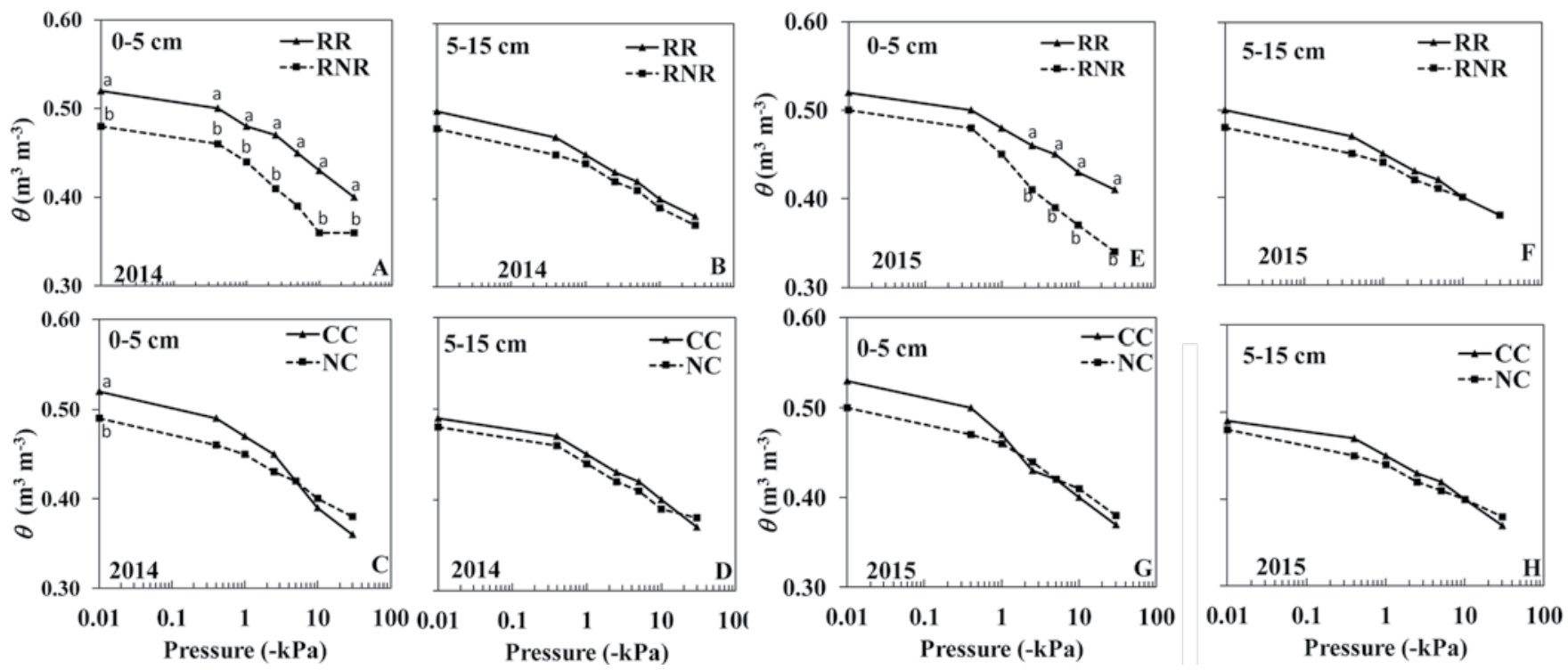

Fig. I. Soil water retention as influenced by residue returned (RR) and residue not returned (RNR), and cover crops for the $0-5$ and $5-15$ $\mathrm{cm}$ depths under soybean ( 9 mo. following residue removal) phase of corn-soybean rotation for $2014(A-D)$ and $2015(E-H)$. The small different letters shown in the figures represent the significant differences in soil water content at different soil water pressures between RR and RNR ( $A$ and E), and cover crops and no cover crops (C). No letters represent the non-significant differences.

that case, the nonsignificant impact of CC could have been due to low CC biomass. Present and previous studies (e.g., Wegner et al., 2015) on the same experimental plot showed that cover crops did not impact SOC.

\section{Infiltration Rate}

In 2014, the residue removal significantly impacted the $q s$ (Fig. 2). The RR had 67\% higher $q$ s as compared to that under the RNR treatment. Similarly, the CC treatment significantly impacted the $q s$. The CC treatment $\left(111 \mathrm{~mm} \mathrm{~h}^{-1}\right)$ had $80 \%$ higher $q$ s compared with NCC treatment $\left(61.7 \mathrm{~mm} \mathrm{~h}^{-1}\right)$. Similar results were observed in 2015 (Fig. 2). The RR $\left(87 \mathrm{~mm} \mathrm{~h}^{-1}\right)$ had $22.5 \%$ higher $q s$ compared with that under RNR treatment $\left(71 \mathrm{~mm} \mathrm{~h}^{-1}\right)$. Similarly, the qs under CC $\left(88.5 \mathrm{~mm} \mathrm{~h}^{-1}\right)$ was $27 \%$ higher than the NCC treatment $\left(69.6 \mathrm{~mm} \mathrm{~h}^{-1}\right)$. Data from the present study showed that the $q s$ under RR was 1.6 and 1.2 times greater compared with RNR for 2014 and 2015, respectively. Similar results were observed in a study conducted at $\mathrm{Swan}$ Lake research farm near Morris, $\mathrm{MN}$, where full return of residue $\left(>7 \mathrm{Mg} \mathrm{ha}^{-1}\right)$ significantly increased $q$ s by two times as compared with that under less return of residue $\left(<2 \mathrm{Mg} \mathrm{ha}^{-1}\right)$ (Johnson et al., 2016). Similarly, another study conducted at Ohio showed that when the residue cover was $100 \%$, the $q$ s was four times greater than when the residue cover was none $(0 \%)$ (Blanco-Canqui and Lal, 2007). Crop residue increases SOC concentration in soil, which stabilizes soil aggregates, reduces soil bulk density, and improves soil porosity which further enhances soil hydrological properties (Blanco-Canqui and Benjamin, 2013; Hammerbeck et al., 2012; Johnson et al., 2016). Data from the present study showed that $q s$ with CC were 1.8 and 1.3 times greater compared with the NCC for 2014 and 2015, respectively. The possible reason for the higher $q s$ with $\mathrm{CC}$ was due to improved soil structure with more and continuous macro and micro pores, root channels, and less compaction. The previous study on the same experimental plots showed greater stability of soil aggregates and smaller erodible fraction for the CC
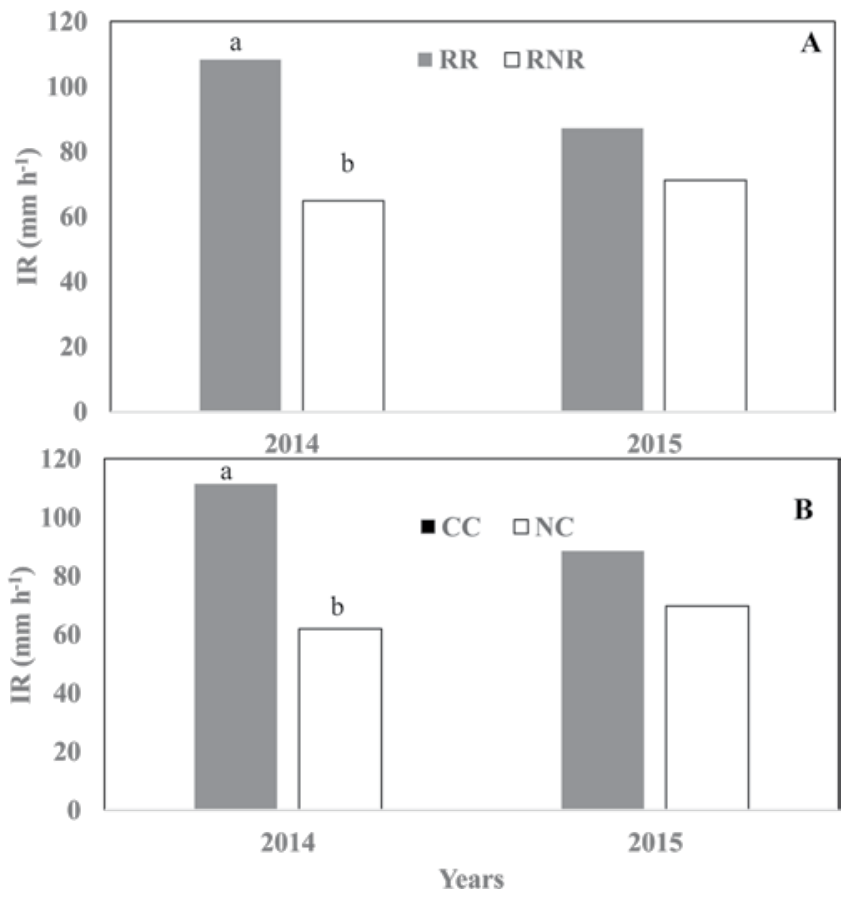

Fig. 2. Soil water infiltration rate (IR) as influenced by residue returned (RR) and residue not returned (RNR), and cover crops under soybean ( 9 months following residue removal) phase of corn-soybean rotation for 2014 and 2015. Small different letters represent the significant differences in infiltration rate are due to residue removal (A) and cover crops (B) for each year.

treatments compared with the NCC treatments (Osborne et al., 2014). Another study conducted in clay loam soil in San Joaquin Valley, CA, showed that infiltration with CC was 2.8 and 2.2 times higher compared with the NCC treatment (Mitchell et al., 2017). Overall, data from the present study suggested that $R R$ and CC treatments resulted in the higher SOC and SWR, lower $\mathrm{BD}$ and SPR, which overall plays significant roles in increasing $q s$ as compared to RNR and NCC treatments. 

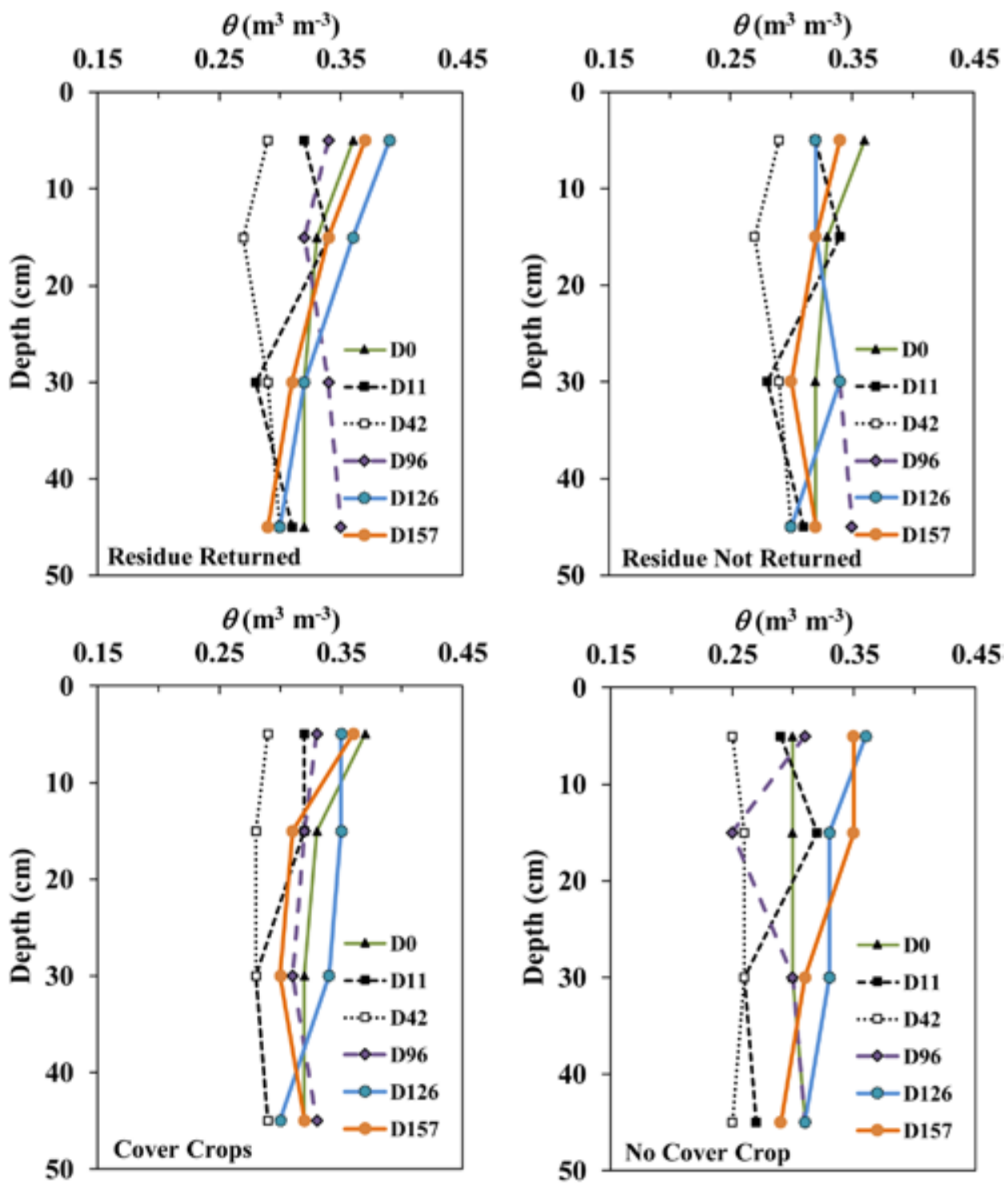

Fig. 3. Volumetric water content $(\theta)$ as influenced by residue returned (RR) and residue not returned (RNR), and cover crops for the 0-5, 5-I5, 15-30 and 30-45 cm depths under soybean. The $\theta$ of samples collected on $0 \mathrm{~d}$ (before planting); II, 42, 96, 126 d (after planting); and $157 \mathrm{~d}$ (after harvesting sample) are represented as D0, DII, D42, D96, DI26, and DI57, respectively.

\section{Volumetric Water Content and Soil Water Storage}

Volumetric water content $(\mathrm{VWC}, \theta)$ of samples collected on $0 \mathrm{~d}$ (before planting sample), 11, 42, 96,126 d (after planting samples), and $157 \mathrm{~d}$ (after harvesting sample) from $0-5,5-15$, $15-30$, and $30-45 \mathrm{~cm}$ depths are presented in Fig. 3 where 0 , $11,42,96,126$, and $157 \mathrm{~d}$ sampling are represented as D0, D11, D42, D96, D126, and D157, respectively. In general, the plots with RR and CC treatment had higher $\theta$ compared with RNR and NCC treatment respectively (Fig. 3). At $0-5 \mathrm{~cm}$ depth, $\theta$ under CC was $16 \%$ higher for 42 -d sampling, compared with that under NCC treatment. For depth $5-15 \mathrm{~cm}, \theta$ under RR treatment was $23 \%$ higher compared with RNR treatment for 96-d sampling. Similarly, $\theta$ for CC treatment was $28 \%$ higher compared with NCC treatment for 96-d sampling. For depth $15-30 \mathrm{~cm}$, the $\theta$ for RR treatment was $26 \%$ higher compared with RNR treatment at 96-d sampling. However, no significant impact of cover crops was observed in this depth.

Present data showed that there was a significant impact of $R R$ treatment compared to RNR treatment on $\theta$. Govaerts
Table 5. Average monthly temperature and monthly precipitation at the experimental site.

\begin{tabular}{lcc}
\hline & Temperature & Precipitation \\
\cline { 2 - 3 } Month & ${ }^{\circ} \mathrm{C}$ & $\mathrm{mm}$ \\
\hline Apr. & $7.7(1.2) \dagger$ & $55.6(-0.1)$ \\
May & $14.1(0.6)$ & $69.5(-14.2)$ \\
June & $21.0(2.0)$ & $95.2(-13.8)$ \\
July & $21.4(0.0)$ & $154.8(71)$ \\
Aug. & $20.9(0.9)$ & $119.3(39.5)$ \\
Sept. & $16.44(1.24)$ & $102.8(24.8)$ \\
Oct. & $9.6(1.9)$ & $48.4(3.7)$ \\
Avg/total & 17.0 & 651 \\
\hline$\dagger$ The numbers in parenthesis is the deviation from $30 \mathrm{yr}$ average.
\end{tabular}


Table 6. Soil water storage (SWS) as influenced by residue returned and residue not returned, and cover crops for the $0-5$ and $5-15 \mathrm{~cm}$ depths under soybean $(9$ mo following residue removal) phase of corn-soybean rotation for 2016.

\begin{tabular}{|c|c|c|c|c|c|c|}
\hline \multirow[b]{3}{*}{ Treatment $\dagger$} & \multicolumn{6}{|c|}{ Days after planting } \\
\hline & 0 & 11 & 42 & 96 & 126 & 157 \\
\hline & \multicolumn{6}{|c|}{$0-5 \mathrm{~cm}$ depth } \\
\hline & \multicolumn{6}{|c|}{ SWS $(\mathrm{mm})$} \\
\hline \multicolumn{7}{|l|}{ Residue } \\
\hline $\mathrm{RR}$ & 23.0a & $20.5 a$ & $18.6 \mathrm{a}$ & $21.9 \mathrm{a}$ & $25.2 \mathrm{a}$ & $23.9 \mathrm{a}$ \\
\hline RNR & $21.4 b$ & $20.0 \mathrm{a}$ & $17.6 \mathrm{a}$ & $21.1 \mathrm{a}$ & $22.0 b$ & $23.5 \mathrm{a}$ \\
\hline \multicolumn{7}{|l|}{ Cover crops } \\
\hline $\mathrm{CC}$ & $24.4 \mathrm{a}$ & $21.2 \mathrm{a}$ & $19.4 \mathrm{a}$ & $20.4 a$ & $23.2 \mathrm{a}$ & $23.6 a$ \\
\hline \multirow[t]{2}{*}{ NCC } & $20.1 b$ & $19.2 \mathrm{a}$ & $16.7 \mathrm{a}$ & $22.7 \mathrm{a}$ & $24.0 \mathrm{a}$ & $23.8 \mathrm{a}$ \\
\hline & \multicolumn{6}{|c|}{ Analysis of variance $(P>F)$} \\
\hline Residue (R) & 0.04 & 0.79 & 0.47 & 0.60 & 0.04 & 0.72 \\
\hline Crop (C) & 0.0001 & 0.25 & 0.08 & 0.17 & 0.54 & 0.89 \\
\hline \multirow[t]{2}{*}{$\mathrm{R} \times \mathrm{C}$} & 0.002 & 0.54 & 0.39 & 0.52 & 0.02 & 0.15 \\
\hline & \multicolumn{6}{|c|}{$5-15 \mathrm{~cm}$ depth } \\
\hline
\end{tabular}

\begin{tabular}{|c|c|c|c|c|c|c|}
\hline \multicolumn{7}{|l|}{ Residue } \\
\hline $\mathrm{RR}$ & 44.1a & $44.8 \mathrm{a}$ & $36.0 \mathrm{a}$ & $43.0 \mathrm{a}$ & $48.2 \mathrm{a}$ & $45.5 \mathrm{a}$ \\
\hline RNR & $41.2 \mathrm{a}$ & $41.8 \mathrm{a}$ & $38.1 \mathrm{a}$ & $35.6 \mathrm{~b}$ & $44.9 \mathrm{a}$ & $45.2 \mathrm{a}$ \\
\hline \multicolumn{7}{|l|}{ Cover crops } \\
\hline $\mathrm{CC}$ & 43. Ia & $42.4 \mathrm{a}$ & $37.0 \mathrm{a}$ & $43.1 \mathrm{a}$ & $46.4 \mathrm{a}$ & $41.9 \mathrm{~b}$ \\
\hline \multirow[t]{2}{*}{ NCC } & 42. Ia & $44.2 \mathrm{a}$ & $37.1 \mathrm{a}$ & $35.5 b$ & $46.6 \mathrm{a}$ & $48.8 \mathrm{a}$ \\
\hline & \multicolumn{6}{|c|}{ Analysis of variance $(P>F)$} \\
\hline Residue (R) & 0.30 & 0.31 & 0.28 & 0.03 & 0.39 & 0.92 \\
\hline Crop (C) & 0.70 & 0.52 & 0.97 & 0.02 & 0.95 & 0.03 \\
\hline $\mathrm{R} \times \mathrm{C}$ & 0.79 & 0.26 & 0.25 & 0.07 & 0.54 & 0.22 \\
\hline
\end{tabular}

†RR, Residue returned; RNR, Residue not returned; CC, cover crop; NCC, no cover crop.

$\ddagger$ Means values followed by different letters within a column for different treatments are significantly different at $P<0.05$.

et al. (2007) also reported higher soil moisture content when residues were retained on the soil surface compared to when the residue were removed. Preserving high moisture at surface depth was due to less evaporation and high SOC at surface depth (VanLoocke et al., 2012; Zhang, 1996). Present data showed fluctuation in soil moisture during planting through harvesting. A study conducted in Iowa concluded that the impact of cover crops on soil moisture depends on the biomass of cover crops (Daigh et al., 2014). The present study suggested that maximum retention of residue is required to maintain higher $\theta$. The reason for higher $\theta$ in RR and CC treatment may be because of returning stover and adopting CC protects the aggregates from breakdown and improves soil physical and hydrological properties (Johnson et al., 2016; Osborne et al., 2014; Stetson et al., 2012).

Table 5 represent average monthly temperature and monthly precipitation on the experimental site for year 2016. Monthly cumulative temperature was generally similar to 30-yr monthly mean temperature. However, monthly average precipitation was higher during the month of July, August, and September. Thus, the conclusion made from this study represents such year with adequate rainfall. Tables 6 and 7 represent the soil water storage (SWS) data for the six sampling days, which include sampling before planting (d 0), and the samples taken 11, 42, 96, $126 \mathrm{~d}$ after planting and after harvesting sampling $(\mathrm{d}-157)$ from the depth $0-5,5-15,15-30$, and $30-45 \mathrm{~cm}$ depth. In general, the plots under RR and CC treatment had higher SWS compared with RNR and NCC treatments, respectively. At the $0-5 \mathrm{~cm}$
Table 7. Soil water storage (SWS) as influenced by residue returned and residue not returned, and cover crops for the 15-30 and $30-45 \mathrm{~cm}$ depths under soybean ( 9 mo following residue removal) phase of corn-soybean rotation for 2016.

\begin{tabular}{|c|c|c|c|c|c|c|}
\hline \multirow[b]{3}{*}{ Treatment $\dagger$} & \multicolumn{6}{|c|}{ Days after planting } \\
\hline & 0 & II & 42 & 96 & 126 & 157 \\
\hline & \multicolumn{6}{|c|}{$15-30 \mathrm{~cm}$ depth } \\
\hline & & & - SWS & $(\mathrm{mm})$ & & \\
\hline \multicolumn{7}{|l|}{ Residue } \\
\hline $\mathrm{RR}$ & 63.5a & $56.0 \mathrm{a}$ & $57.4 a$ & $68.0 \mathrm{a}$ & $64.7 b$ & $62.7 a$ \\
\hline RNR & $63.6 \mathrm{a}$ & $55.8 \mathrm{a}$ & $52.5 a$ & $57.0 \mathrm{~b}$ & $71.9 \mathrm{a}$ & $63.1 \mathrm{a}$ \\
\hline \multicolumn{7}{|l|}{ Cover crops } \\
\hline $\mathrm{CC}$ & $64.0 \mathrm{a}$ & $56.9 a$ & $56.3 a$ & $61.4 \mathrm{a}$ & $67.2 \mathrm{a}$ & $59.8 b$ \\
\hline \multirow[t]{2}{*}{$\mathrm{NCC}$} & $63.1 \mathrm{a}$ & $54.8 \mathrm{a}$ & $53.6 a$ & $63.6 a$ & $69.5 \mathrm{a}$ & $66.0 \mathrm{a}$ \\
\hline & \multicolumn{6}{|c|}{ Analysis of variance $(P>F)$} \\
\hline Residue (R) & 0.94 & 0.94 & 0.26 & 0.03 & 0.03 & 0.88 \\
\hline Crop (C) & 0.64 & 0.53 & 0.53 & 0.59 & 0.39 & 0.04 \\
\hline \multirow[t]{2}{*}{$\mathrm{R} \times \mathrm{C}$} & 0.55 & 0.65 & 0.13 & 0.52 & 0.07 & 0.97 \\
\hline & \multicolumn{6}{|c|}{$30-45 \mathrm{~cm}$ depth } \\
\hline \multicolumn{7}{|l|}{ Residue } \\
\hline $\mathrm{RR}$ & 67.1a & $65.3 a$ & $62.1 \mathrm{a}$ & $73.3 a$ & $63.2 \mathrm{a}$ & $60.4 b$ \\
\hline RNR & $68.5 \mathrm{a}$ & $54.1 \mathrm{~b}$ & $51.5 b$ & $63.7 b$ & $65.3 a$ & $69.0 \mathrm{a}$ \\
\hline \multicolumn{7}{|l|}{ Cover crops } \\
\hline $\mathrm{CC}$ & $67.2 \mathrm{a}$ & $59.4 a$ & $59.0 \mathrm{a}$ & $68.6 \mathrm{a}$ & $61.8 \mathrm{a}$ & $66.0 \mathrm{a}$ \\
\hline \multirow[t]{2}{*}{$\mathrm{NCC}$} & $68.4 \mathrm{a}$ & $60.1 \mathrm{a}$ & $54.6 a$ & $68.4 a$ & $66.8 \mathrm{a}$ & $63.4 \mathrm{a}$ \\
\hline & \multicolumn{6}{|c|}{ Analysis of variance $(P>F)$} \\
\hline Residue (R) & 0.70 & 0.004 & 0.003 & 0.001 & 0.64 & 0.003 \\
\hline Crop (C) & 0.73 & 0.76 & 0.09 & 0.90 & 0.30 & 0.18 \\
\hline $\mathrm{R} \times \mathrm{C}$ & 0.73 & 0.53 & 0.06 & 0.04 & 0.60 & 0.60 \\
\hline
\end{tabular}

$\uparrow R R$, residue returned; RNR, residue not returned; CC, cover crop; NCC, no cover crop.

$\ddagger$ Means values followed by different letters within a column for different treatments are significantly different at $P<0.05$.

depth, RR treatment increased SWS by 7 and $14.5 \%$ for the $0-\mathrm{d}$ and 126-d sampling, respectively, compared to the RNR treatment. The interaction between residue by cover crops was significant for 0 -d and 126-d sampling $(P<0.05$; Table 6). For the $5-15 \mathrm{~cm}$ depth, SWS with RR treatment was significantly higher by $20.7 \%$ as compared to that under RNR treatment at 96-d sampling. No significant interaction between cover crops and crop residue was observed for this depth. For $15-30 \mathrm{~cm}$ depth, residue removal treatment significantly impacted SWS on 96-d and 126-d sampling. The SWS on RR treatment was $19 \%$ higher compared with RNR treatment at 96-d sampling. However, for 126-d sampling, the RNR had significantly higher SWS by $11 \%$ compared with that under RR treatments. Significant impact of CC treatment was observed on 157-d sampling. The NCC had significantly higher SWS by $10 \%$ compared with that under CC treatments. The interactions between residue and $\mathrm{CC}$ were not significant for this depth. For the 30-45 cm depth, significant impact of CC treatment was observed on 11-d, 42-d, and 157-d sampling. The SWS for RR treatment was higher by 20.7 and $20.5 \%$ compared with RNR treatment for 11 and 42-d sampling, respectively. However, for the $157-\mathrm{d}$ sampling, the RNR had significantly higher SWS by $14 \%$ compared with RR treatment. No significant impact of cover crops was observed for this depth through the season. The interaction between residue and CC was significant $(P<0.05$; Table 7) on 96-d sampling for 30-45 cm depth. Significant interactions were observed on $0 \mathrm{~d}$ for $0-5 \mathrm{~cm}$ depth and $126 \mathrm{~d}$ 
Table 8. Interaction effects of residue and cover crops on soil water storage (SWS) under soybean (9 mo following residue removal) phase of corn-soybean rotation. $\dagger$

\begin{tabular}{|c|c|c|c|c|c|c|}
\hline \multirow[b]{4}{*}{ Treatment } & \multicolumn{6}{|c|}{ SWS } \\
\hline & \multicolumn{2}{|c|}{$0 \mathrm{~d}$} & \multicolumn{2}{|c|}{$126 d$} & \multicolumn{2}{|c|}{$96 d$} \\
\hline & \multicolumn{4}{|c|}{$0-5 \mathrm{~cm}$} & \multicolumn{2}{|c|}{$30-45 \mathrm{~cm}$} \\
\hline & $\mathrm{CC}$ & NCC & CC & $\mathrm{NCC}$ & CC & $\mathrm{NCC}$ \\
\hline $\mathrm{RR}$ & $26.7 \mathrm{a} A$ & $19.2 \mathrm{aB}$ & $26.7 \mathrm{aA}$ & $23.6 \mathrm{aA}$ & 75.5aA & $71.0 \mathrm{aA}$ \\
\hline RNR & $22.0 \mathrm{bA}$ & $20.8 \mathrm{aA}$ & $19.6 \mathrm{aB}$ & $24.3 \mathrm{aA}$ & $61.8 \mathrm{bA}$ & $65.7 \mathrm{aA}$ \\
\hline
\end{tabular}

$\dagger R R$, residue returned; RNR, residue not returned; CC, cover crop; NCC, no cover crop.

$\ddagger$ Average value followed by same lowercase letter within a column and by capital letter within row are not significantly different at $P<0.05$.

for $0-5 \mathrm{~cm}$ and $30-45 \mathrm{~cm}$ depth (Table 8). For 0-d sampling, the RR with CC treatments had significantly higher SWS (39\%) compared to the RR with NCC treatment $0-5 \mathrm{~cm}$ depth. Similarly, the RR with CC treatments had $21 \%$ higher SWS compared under RNR with CC treatments. However, for 126-d sampling, the RNR with NCC had higher SWS by $24 \%$ compared with RNR with CC treatments for $0-5 \mathrm{~cm}$ depth. For $30-45 \mathrm{~cm}$ depth, the RR with CC treatments had significantly higher SWS by $22 \%$ compared with RNR with CC treatments.

Data from the present study showed that RR treatment had higher SWS compared to RNR treatments in $0-5 \mathrm{~cm}$ depth. Results corroborating these findings were observed in a study where the addition of mulch in no-till soybean cropping system increased mean seasonal soil water storage by 55 and $59 \mathrm{~mm}$ in years 2006 and 2007 respectively, compared to no mulch added (Obalum et al., 2011). Data from the present study showed that, in general, CC treatment has higher SWS compared with NCC treatments. Similar results were observed in another study conducted in Iowa where long-term $(>14 \mathrm{yr})$ use of winter rye CC increased soil water storage (Basche et al., 2016b). Several previous studies showed that cover crops can reduce water availability for next crops in semiarid and water limited areas (Nielsen et al., 2015; Nielsen et al., 2016). However, another study conducted in Iowa showed that winter cover crops increased SWS during the drought of 2012 (Daigh et al., 2014). The interactions showed that, in general, RR with CC treatment increased SWS compared with RR with NCC. Similarly, SWS was higher under RR with CC compared with RNR with CC. However, on 126-d sampling RNR with NCC had 24\% higher SWS. This inconsistent effects may have been due to seeding of cover crops. The 126-d samples were taken after the seeding of cover crops. Similar results were observed on the previous study, which showed that cover crops reduced SWS compared with no cover crop treatment (Gabriel et al., 2012; Nielsen et al., 2016). Another reason could be due to enough precipitation occur in the month of September. Rainfall during the month was above average which may fill soil profile in all CC, NCC, RR, and RNR plots. However, the present study was designed to observed impacts of cover crops on the soybean growing season. Our results indicate that cover crops did not negatively impact the SWS for the soybean growing season i.e., May through August sampling.

\section{Soybean Yield}

Residue removal and CC effects on soybean yield are presented in Table 9. No significant impacts of residue removal
Table 9. Grain yield as influenced by residue returned and residue not returned, and cover crops and no cover crop treatment under soybean ( 9 mo following residue removal) phase of corn-soybean rotation for 2016 .

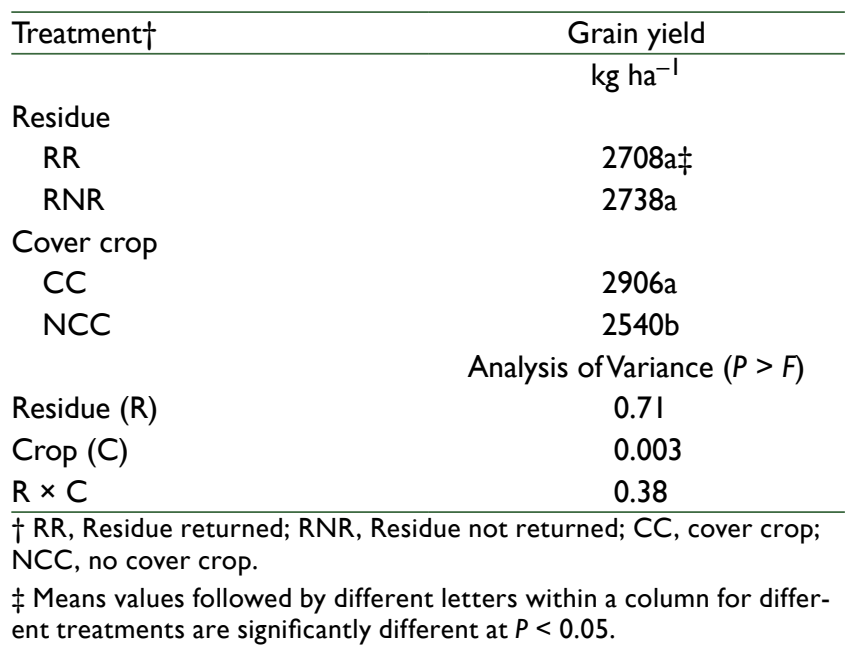

treatment were observed on grain yield (Table 9). However, cover crops significantly impacted grain yield. There was an increase in soybean yield by $14 \%$ with CC treatment compared with that of NCC treatment. The interaction between cover crops and crop residue on grain yield were not statistically significant. A study conducted on Loess Plateau showed that the addition of leguminous CC increased wheat yield by $28 \%$ (Zhang et al., 2016). However, Kramberger et al. (2009) reported reduction of crop yield due to competition for water by cover crops, whereas Basche et al. (2016b) reported that long-term use of cover crops improved soil water dynamics. Data from the present study suggested that the use of cover crops has positive impacts on soil hydrological properties such as water infiltration and water retention, those eventually help to store more water in the soil profile. Additionally, improved soil aggregate size distribution and a lower erodible fraction can be beneficial in conserving the soil moisture, and enhancing the crop yield.

\section{CONCLUSIONS}

The Northern Great Plains region of the United States is very important for corn-soybean production, but very little is known about the impacts of cover crops and corn residues on soil properties. The present study was conducted to make a comprehensive understanding of the impacts of cover crops and crop residue on soil hydrological properties and soybean yield. Data showed that RR increased SOC and TN as compared to that under RNR at the $0-5 \mathrm{~cm}$ depth. Further, the incorporation of cover crops in RR treatment resulted in lower soil bulk density compared under RNR with NCC treatment for the $0-5$ $\mathrm{cm}$ depth in 2014 . The RR treatment reduced bulk density in 2015 compared to that under RNR. Soil bulk density was lower under RR compared with RNR for $0-5$ and $5-15 \mathrm{~cm}$ depths in 2016 (after $16 \mathrm{yr}$ of residue returned practice).

Soil water retention was higher under RR treatment as compared to RNR treatment in the $0-5 \mathrm{~cm}$ depth. The infiltration rate was 1.6 and 1.2 times higher in $R R$ treatment compared with the RNR treatment in 2014 and 2015, respectively. Similarly, infiltration rate was 1.8 and 1.3 times higher in CC treatment compared with NCC treatment for 2014 and 2015, respectively. Volumetric water content and soil water storage 
were, in general, higher under the RR treatment compared to RNR treatment. Similarly, volumetric moisture content and soil water storage were, in general, higher under the CC treatment compared to NCC treatment. However, the trend was not consistent from May through October sampling days. There was an increase in soybean yield by $14 \%$ with CC treatments compared with NCC treatment. However, no significant impact of residue removal treatment was observed on grain yield.

This study suggests that residue returned with incorporation of cover crops is beneficial for improving the soil hydrological properties compared to those with residue not returned without cover crop treatments.

\section{ACKNOWLEDGMENTS}

This study was part of a project supported by the USDA-NIFA (award 2014-51130-22593) and the project entitled "Integrated plan for drought preparedness and mitigation, and water conservation at the watershed scale." Authors would like to thank Seth Owens, Saroop Sandhu, and Brant Douville for the help during soil sampling.

\section{REFERENCES}

Acuña, J.C.M., and M.B. Villamil. 2014. Short-term effects of cover crops and compaction on soil properties and soybean production in Illinois. Agron. J. 106:860-870. doi:10.2134/agronj13.0370

Alliaume, F., W.A.H. Rossing, P. Tittonell, G.Jorge, and S. Dogliotti. 2014. Reduced tillage and cover crops improve water capture and reduce erosion of fine textured soils in raised bed tomato systems. Agric. Ecosyst. Environ. 183:127-137. doi:10.1016/j.agee.2013.11.001

Amoozegar, A., and G.V. Wilson. 1999. Methods for measuring hydraulic conductivity and drainable porosity. Agricultural drainage. Agronomy No. 38. ASA, Madison, WI. p. 1149-1205.

Basche, A., and M. DeLonge. 2017. The impact of continuous living cover on soil hydrologic properties: A meta-analysis. Soil Sci. Soc. Am. J. 81:1179-1190. doi:10.2136/sssaj2017.03.0077

Basche, A.D., S.V. Archontoulis, T.C. Kaspar, D.B. Jaynes, T.B. Parkin, and F.E. Miguez. 2016a. Simulating long-term impacts of cover crops and climate change on crop production and environmental outcomes in the Midwestern United States. Agric. Ecosyst. Environ. 218:95-106. doi:10.1016/j.agee.2015.11.011

Basche, A.D., T.C. Kaspar, S.V. Archontoulis, D.B. Jaynes, T.J. Sauer, T.B. Parkin, and F.E. Miguez. 2016b. Soil water improvements with the long-term use of a winter rye cover crop. Agric. Water Manage. 172:40-50. doi:10.1016/j.agwat.2016.04.006

Blanco-Canqui, H., and J.G. Benjamin. 2013. Impacts of soil organic carbon on soil physical behavior. In: S. Logsdon, M. Berli, and R. Horn, editors, Quantifying and modeling soil structure dynamics, Adv. Agric. Syst. Model. 3. SSSA, Madison, WI. p. 11-40, doi:10.2134/ advagricsystmodel3.c2.

Blanco-Canqui, H., R.B. Ferguson, V.L. Jin, M.R. Schmer, B.J. Wienhold, and J. Tatarko. 2014. Can cover crop and manure maintain soil properties after stover removal from irrigated no-till corn? Soil Sci. Soc. Am. J. 78:1368-1377. doi:10.2136/sssaj2013.12.0550

Blanco-Canqui, H., and R. Lal. 2007. Soil and crop response to harvesting corn residues for biofuel production. Geoderma 141(3-4):355-362. doi:10.1016/j.geoderma.2007.06.012

Blanco-Canqui, H., and R. Lal. 2009a. Corn stover removal for expanded uses reduces soil fertility and structural stability. Soil Sci. Soc. Am. J. 73:418-426. doi:10.2136/sssaj2008.0141

Blanco-Canqui, H., and R. Lal. 2009b. Crop residue removal impacts on soil productivity and environmental quality. Crit. Rev. Plant Sci. 28:139-163.
Blanco-Canqui, H., C.A. Shapiro, C.S. Wortmann, R.A. Drijber, M. Mamo, T.M. Shaver, and R.B. Ferguson. 2013. Soil organic carbon: The value to soil properties. J. Soil Water Conserv. 68:129A-134A. doi:10.2489/jswc.68.5.129A

Blanco-Canqui, H., T.M. Shaver, J.L. Lindquist, C.A. Shapiro, R.W. Elmore, C.A. Francis, and G.W. Hergert. 2015. Cover crops and ecosystem services: Insights from studies in temperate soils. Agron. J. 107:2449-2474. doi:10.2134/agronj15.0086

Box, G., and D. Cox. 1981. An analysis of transformations revisited, rebutted. J. Am. Stat. Assoc. 77(377):209-210. doi:10.1080/01621459.19 82.10477788

Box, G.E., and D.R. Cox. 1964. An analysis of transformations. J. R. Stat. Soc. [Ser A] 26:211-252.

Busscher, W., and P. Bauer. 2003. Soil strength, cotton root growth and lint yield in a southeastern USA coastal loamy sand. Soil Tillage Res. 74:151-159. doi:10.1016/j.still.2003.06.002

Chahal, I., and L.L. Van Eerd. 2018. Evaluation of commercial soil health tests using a medium-term cover crop experiment in a humid, temperate climate. Plant Soil 2018:1-17.

Chu, M., S. Jagadamma, F.R. Walker, N.S. Eash, M.J. Buschermohle, and L.A. Duncan. 2017. Effect of multispecies cover crop mixture on soil properties and crop yield. Agric. Environ. Lett. 2:170030. doi:10.2134/ael2017.09.0030

Daigh, A.L., M.J. Helmers, E. Kladivko, X. Zhou, R. Goeken, J. Cavdini, D. Barker, and J. Sawyer. 2014. Soil water during the drought of 2012 as affected by rye cover crops in fields in Iowa and Indiana. J. Soil Water Conserv. 69:564-573. doi:10.2489/jswc.69.6.564

Das, A., P. Rushton, and J.S. Rohila. 2017. Metabolomic profiling of soybeans (Glycine max L.) reveals the importance of sugar and nitrogen metabolism under drought and heat stress. Plants 6(2):21. doi:10.3390/plants6020021

Dolan, M., C. Clapp, R. Allmaras, J. Baker, and J. Molina. 2006. Soil organic carbon and nitrogen in a Minnesota soil as related to tillage, residue and nitrogen management. Soil Tillage Res. 89:221-231. doi:10.1016/j.still.2005.07.015

Gabriel, J.L., R. Muñoz-Carpena, and M. Quemada. 2012. The role of cover crops in irrigated systems: Water balance, nitrate leaching and soil mineral nitrogen accumulation. Agric. Ecosyst. Environ. 155:50-61. doi:10.1016/j.agee.2012.03.021

Govaerts, B., M. Fuentes, M. Mezzalama, J.M. Nicol, J. Deckers, J.D. Etchevers, B. Figueroa-Sandoval, and K.D. Sayre. 2007. Infiltration, soil moisture, root rot and nematode populations after 12 years of different tillage, residue and crop rotation managements. Soil Tillage Res. 94:209-219. doi:10.1016/j.still.2006.07.013

Grossman, R.B., and T.G. Reinsch. 2002. Bulk density and linear extensibility. In: J.H. Dane and C.G. Topp, editors, Methods of soil analysis: Part 4 physical methods. SSSA Book Ser. Soil Science Society of America, Madison, WI. p. 201-228.

Hammerbeck, A.L., S.J. Stetson, S.L. Osborne, T.E. Schumacher, and J.L. Pikul. 2012. Corn residue removal impact on soil aggregates in a no-till corn/soybean rotation. Soil Sci. Soc. Am. J. 76:1390-1398. doi:10.2136/sssaj2011.0421

Herrick, J.E., and T.L. Jones. 2002. A dynamic cone penetrometer for measuring soil penetration resistance Joint contribution from the USDA-ARS Jornada Experimental Range, and the New Mexico Agric. Exp. Stn. Soil Sci. Soc. Am. J. 66:1320-1324. doi:10.2136/ sssaj2002.1320

Iqbal, A., J. Beaugrand, P. Garnier, and S. Recous. 2013. Tissue density determines the water storage characteristics of crop residues. Plant Soil 367(1):285-299. doi:10.1007/s11104-012-1460-8

Jägermeyr, J., D. Gerten, S. Schaphoff, J. Heinke, W. Lucht, and J. Rockstrom. 2016. Integrated crop water management might sustainably halve the global food gap. Environ. Res. Lett. 11:025002. doi:10.1088/1748-9326/11/2/025002 
Johnson, J.M., J.S. Strock, J.E. Tallaksen, and M. Reese. 2016. Corn stover harvest changes soil hydrology and soil aggregation. Soil Tillage Res. 161:106-115. doi:10.1016/j.still.2016.04.004

Kahimba, F., R.S. Ranjan, J. Froese, M. Entz, and R. Nason. 2008. Cover crop effects on infiltration, soil temperature, and soil moisture distribution in the Canadian Prairies. Appl. Eng. Agric. 24:321-333. doi:10.13031/2013.24502

Karlen, D.L., S.J. Birrell, J.M.F. Johnson, S.L. Osborne, T.E. Schumacher, G.E. Varvel, R.B. Ferguson, J.M. Novak, J.R. Ferdrick, J.M. Baker, J.A. Lamb, P.R. Adler, G.W. Roth, and E.D. Nafziger. 2014. Multilocation corn stover harvest effects on crop yields and nutrient removal. BioEnergy Res. 7:528-539. doi:10.1007/s12155-014-9419-7

Klute, A. 1986. Methods of soil analysis: Part 1-Physical and mineralogical methods. SSSA Book Ser. 5.1. 91:635-662. SSSA, ASA, Madison, WI.

Kramberger, B., A. Gselman, M. Janzekovic, M. Kaligaric, and B. Bracko. 2009. Effects of cover crops on soil mineral nitrogen and on the yield and nitrogen content of maize. Eur. J. Agron. 31(2):103-109. doi:10.1016/j.eja.2009.05.006

Mann, L., V. Tolbert, and J. Cushman. 2002. Potential environmental effects of corn (Zea mays L.) stover removal with emphasis on soil organic matter and erosion. Agric. Ecosyst. Environ. 89(3):149-166. doi:10.1016/S0167-8809(01)00166-9

Mitchell, J.P., A. Shrestha, K. Mathesius, K.M. Scow, R.J. Southard, R.L. Haney, R. Schmidt, D.S. Munk, and W.R. Horwath. 2017. Cover cropping and no-tillage improve soil health in an arid irrigated cropping system in California's San Joaquin Valley, USA. Soil Tillage Res. 165:325-335. doi:10.1016/j.still.2016.09.001

Moebius-Clune, B.N., H.M. Es, O.J. Idowu, R.R. Schindelbeck, D.J. Moebius-Clune, D.W. Wolfe, G.S. Abawi, J.E. Thies, B.K. Gugino, and R. Lucey. 2008. Long-term effects of harvesting maize stover and tillage on soil quality. Soil Sci. Soc. Am. J. 72:960-969. doi:10.2136/ sssaj2007.0248

Muth, D.J., K.M. Bryden, and R. Nelson. 2013. Sustainable agricultural residue removal for bioenergy: A spatially comprehensive US national assessment. Appl. Energy 102:403-417. doi:10.1016/j. apenergy.2012.07.028

Muth, D.J., and K.M. Bryden. 2013. An integrated model for assessment of sustainable agricultural residue removal limits for bioenergy systems. Environ. Model. Softw. 39:50-69. doi:10.1016/j. envsoft.2012.04.006

Nielsen, D.C., D.J. Lyon, G.W. Hergert, R.K. Higgins, and J.D. Holman. 2015. Cover crop biomass production and water use in the central great plains. Agron. J. 107:2047-2058. doi:10.2134/agronj15.0186

Nielsen, D.C., M.F. Vigil, D.J. Lyon, R.K. Higgins, G.W. Hergert, and J.D. Holman. 2016. Cover crops can affect subsequent wheat yield in the Central Great Plains. Crops Soils 49(3):51-53. doi:10.2134/ cs2016.49.0315
Obalum, S.E., C.A. Igwe, M.E. Obi, and T. Wakatsuki. 2011. Water use and grain yield response of rainfed soybean to tillage-mulch practices in southeastern Nigeria. Sci. Agric. 68:554-561. doi:10.1590/ S0103-90162011000500007

Olson, K.R., S.A. Ebelhar, and J.M. Lang. 2010. Cover crop effects on crop yields and soil organic carbon content. Soil Sci. 175(2):89-98. doi:10.1097/SS.0b013e3181cf7959

Osborne, S.L., J.M.F. Johnson, V.L. Jin, A.L. Hammerbeck, G.E. Varvel, and T.E. Schumacher. 2014. The impact of corn residue removal on soil aggregates and particulate organic matter. BioEnergy Res. 7:559-567. doi:10.1007/s12155-014-9413-0

Rawls, W.J., Y.A. Pachepsky, J.C. Ritchie, T.M. Sobecki, and H. Bloodworth. 2003. Effect of soil organic carbon on soil water retention. Geoderma 116(1-2):61-76. doi:10.1016/S0016-7061(03)00094-6

Reynolds, W.D., D.E. Elrick, E.G. Youngs, and H.W.G. Booltink. 2002. Saturated and field-saturated water flow parameters. Methods of soil analysis. 4:797-801.

SAS. 2013. SAS Institute. The SAS system for Windows. Release 9.4. SAS Inst., Cary, NC.

Steduto, P. 2012. Crop yield response to water. Food and Agriculture Organization of the United Nations, Rome.

Stetson, S.J., S.L. Osborne, T.E. Schumacher, A. Eynard, G. Chilom, J. Rice, K.A. Nichols, and J.L. Pikul, Jr. 2012. Corn residue removal impact on topsoil organic carbon in a corn-soybean rotation. Soil Sci. Soc. Am. J. 76:1399-1406. doi:10.2136/sssaj2011.0420

Tormena, C.A., D.L. Karlen, S. Logsdon, and M.R. Cherubin. 2017. Corn stover harvest and tillage impacts on near-surface soil physical quality. Soil Tillage Res. 166:122-130. doi:10.1016/j.still.2016.09.015

Unger, P.W., and M.F. Vigil. 1998. Cover crop effects on soil water relationships. J. Soil Water Conserv. 53:200-207.

Van Donk, S.J., D.L. Martin, S. Irmak, S.R. Melvin, J.L. Petersen, and D.R. Davison. 2010. Crop residue cover effects on evaporation, soil water content, and yield of deficit-irrigated corn in west-central Nebraska. Trans. ASABE 53:1787-1797. doi:10.13031/2013.35805

VanLoocke, A., T.E. Twine, M. Zeri, and C.J. Bernacchi. 2012. A regional comparison of water use efficiency for miscanthus, switchgrass and maize. Agric. For. Meteorol. 164:82-95. doi:10.1016/j. agrformet.2012.05.016

Wegner, B.R., S. Kumar, S.L. Osborne, T.E. Schumacher, I.E. Vahyala, and A. Eynarde. 2015. Soil response to corn residue removal and cover crops in eastern South Dakota. Soil Sci. Soc. Am. J. 79:11791187. doi:10.2136/sssaj2014.10.0399

Zhang, D., P. Yao, Z. Na, W. Cao, S. Zhang, Y. Li, and Y. Gao. 2016. Soil water balance and water use efficiency of dryland wheat in different precipitation years in response to green manure approach. Sci. Rep. 6. doi: $10.1038 /$ srep26856

Zhang, Z. 1996. Corn yield response to cover crops and N rates under long-term conventional and no-tillage management. J. Sustain. Agric. 8:61-72.doi:10.1300/J064v08n01_08 